\title{
Development of an Equine Antitoxin by Immunizing the Halla Horse with the Receptor-Binding Domain of Botulinum Neurotoxin Type A1
}

Na Young Kim ${ }^{1}$, Kyung-eui Park ${ }^{1}$, Yong Jin Lee', Yeong Mun Kim ${ }^{1}$, Sung Hyun Hong', Won Rak Son ${ }^{1}$, Sungyoul Hong' ${ }^{2}$, Saehyung Lee ${ }^{2}$, Hye Bin Ahn ${ }^{3}$, Jaehyuk Yang ${ }^{4}$, Jong-pil Seo ${ }^{5}$, Yoon-Kyu Lim ${ }^{5}$, Chi Ho Yu ${ }^{6}$, Gyeung Haeng Hur ${ }^{6}$, Seong Tae Jeong ${ }^{6}$, Hun Seok Lee ${ }^{7}$, Kyoung Song ${ }^{8}$, Tae Jin Kang ${ }^{9}$, Young Kee Shin ${ }^{2,3}$, Joon-Seok Choi ${ }^{10 *}$, and Jun Young Choi ${ }^{1,2 *}$

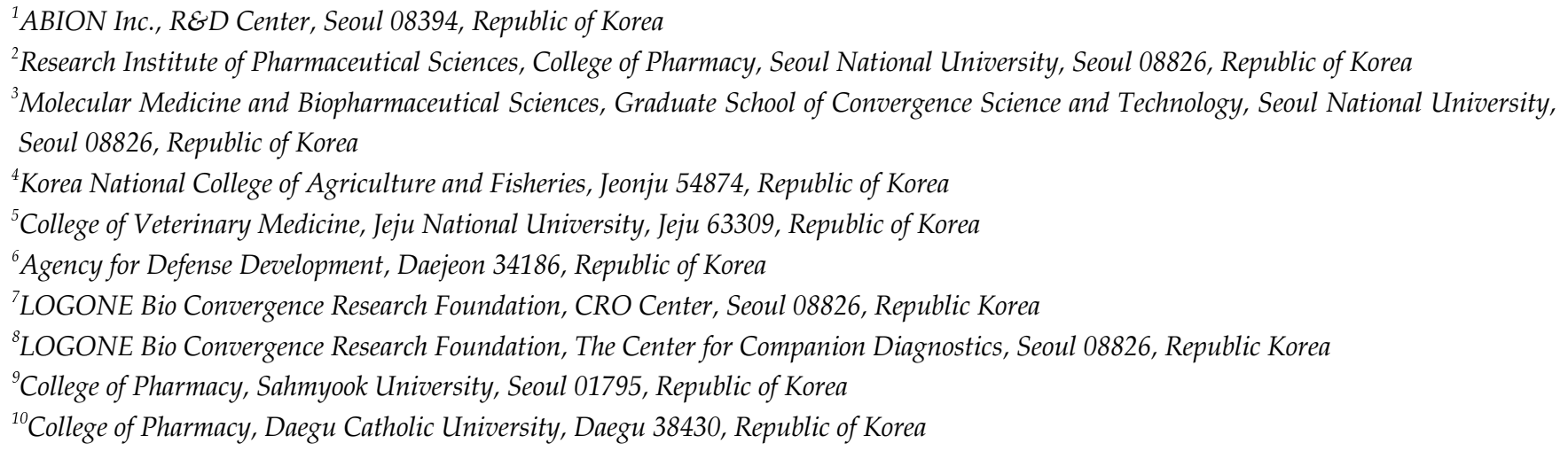

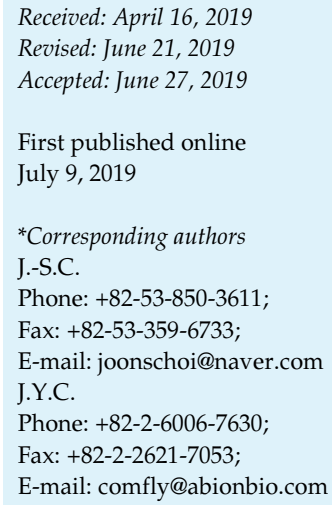

Botulinum neurotoxins (BoNTs), produced by Clostridium botulinum, are the most toxic substances known. However, the number of currently approved medical countermeasures for these toxins is very limited. Therefore, studies on therapeutic antitoxins are essential to prepare for toxin-related emergencies. Currently, more than 10,000 Halla horses, a crossbreed between the native Jeju and Thoroughbred horses, are being raised in Jeju Island of Korea. They can be used for equine antitoxin experiments and production of hyperimmune serum against BoNT/A1. Instead of the inactivated BoNT/A1 toxoid, Halla horse was immunized with the receptor-binding domain present in the C-terminus of heavy chain of BoNT/A1 (BoNT/A1-HCR) expressed in Escherichia coli. The anti-BoNT/A1-HCR antibody titer increased rapidly by week 4 , and this level was maintained for several weeks after boosting immunization. Notably, $20 \mu \mathrm{l}$ of the week-24 BoNT/A1-HCR(-immunized) equine serum showed an in vitro neutralizing activity of over 8 international units (IU) of a reference equine antitoxin. Furthermore, $20 \mu \mathrm{l}$ of equine serum and $100 \mu \mathrm{g}$ of purified equine $\mathrm{F}\left(\mathrm{ab}^{\prime}\right)_{2}$ showed $100 \%$ neutralization of $10,000 \mathrm{LD}_{50}$ in vivo. The results of this study shall contribute towards optimizing antitoxin production for BoNT/A1, which is essential for emergency preparedness and response.

Keywords: Equine antitoxin, botulinum neurotoxin type A, Halla horse

\section{Introduction}

In the targeted area, biological warfare agents exclusively affect living organisms, without damaging potentially valuable non-living things. Botulinum neurotoxins (BoNTs) have been among the first candidates to be considered for bioterrorism because they can be easily manufactured, stored, and dispersed [1-4]. They can also have a ripple 
effect mediated via social chaos.

Botulism, a fatal paralyzing disease, is caused by potent BoNTs produced by the anaerobic gram-positive sporeforming bacterium Clostridium botulinum. BoNTs are categorized into eight serotypes - A to H. Serotypes A, B, E, and rarely $F$ and $G$ cause disease in humans, while serotypes $\mathrm{C}$ and $\mathrm{D}$ can only cause disease in animals, including cattle and birds $[5,6]$. BoNT/H is a novel botulinum toxin that is produced by the bivalent Clostridium botulinum strain, IBCA10-7060. This strain, which produces BoNT/B and BoNT/H, was isolated from an infant patient with botulism. BoNT/H is not neutralized by antitoxins to BoNT A-G [7]. Among the eight distinct exotoxins, BoNT/A is the most potent, followed by types B and $\mathrm{F}$ [8].

BoNTs are composed of a $50 \mathrm{kDa}$ light chain (LC) and a $100 \mathrm{kDa}$ heavy chain (HC), linked by a single disulfide bond. The N-terminal catalytic LC has zinc metalloprotease activity, while the HC contains two functional domains: a translocation domain and a receptor-binding domain [9, 10]. BoNTs can enter the human body through the respiratory system (inhalational botulism) [11], gastrointestinal tract (foodborne and infant botulism), and infected wounds (wound botulism) [12-14]. Upon infection, the circulatory system transports the BoNT to the peripheral nerves, where it mainly targets the neuromuscular junctions. In the neurons, BoNT/B, D, F, and G proteolyze VAMP [15-17], and BoNT/A, C, and E cleave SNAP-25 [18, 19]. This ultimately leads to the inhibition of acetylcholine exocytosis, thereby inducing neuromuscular paralysis [20].

Medical countermeasures against potential biothreats for mass destruction using BoNT/A are necessary. For the large volumes of high titer plasma to support large-scale antitoxin production, high yields of neutralizing antibodies should be generated rapidly in animals (e.g., horses, sheep, and goats), and the resulting hyperimmune sera can be easily processed to make a product suitable for human use $[21,22]$. BabyBIG consists of human serum-derived antiBoNT polyclonal antibodies, and is approved by the FDA for the treatment of infant botulism types A and B [20, 23]. However, its use is limited for the treatment of adults due to its low potency and high cost [24]. Heptavalent botulism antitoxin (H-BATTM) is an antitoxin for BoNT serotypes A to $G[25,26]$, and was approved by the FDA in March 2013. H-BATTM is being supplied to the US government to be included in the Strategic National Stockpile (SNS). However, it is very expensive and available in limited quantities for exporting outside the US, which makes it necessary to produce antitoxins using local domestic horses. In fact, the previous studies on antitoxins for BoNT/A have been reported consistently since 1980's [27, 28], However, the first-line treatment for BoNT/A is produced only in the US, and exports are limited, making it difficult for the Republic of Korea to be prepared for emergency medical treatment for botulinum intoxication [29].

Currently, around 26,000 horses are being bred in the Republic of Korea, with 14,776 (57.2\%) of them being bred on Jeju Island [30]. Horses bred on Jeju Island are subdivided into Jeju (6.1\%), Thoroughbred (18.8\%), and Halla $(75.1 \%)$ horses. Halla horses are a crossbreed between the Jeju and Thoroughbred horses, and are used for horse racing, riding, and meat production [31]. Among more than 10,000 Halla horses in Jeju Island, some portion of them can be utilized for antitoxin production.

The purpose of this study was to examine the proof of concept for production of horse serum against botulinum toxins in emergency situations, and to investigate the possibility of producing an antitoxin against BoNT/A1 in the Korean domestic Halla horse using BoNT/A1-HCR, instead of using the inactivated toxoid or toxin which was used as the antigen to produce H-BAT. Collectively, our data using mouse and rabbit models confirm the antigenicity and safety of the selected antigens. We subsequently immunized a healthy, well-maintained Halla horse, and evaluated the in vitro and in vivo neutralization activities of our antitoxin.

\section{Materials and Methods}

\section{Materials}

pET-28a vector was purchased from Novagen (UK). The $0.45 \mu \mathrm{m}$ MF membrane filters were purchased from Millipore (USA). The Ni-NTA resin column was purchased from Qiagen (Germany) and thrombin was purchased from GE Healthcare (UK). Alhydrogen adjuvant was purchased from InvivoGen (USA). Goat anti-mouse antibody (IgG-HRP), Goat anti-rabbit antibody (IgG-HRP), Ganglioside, and Anti-beta-actin antibody were purchased from Santa Cruz Biotechnology (USA). Aluminum hydroxide gel $(0.6 \mathrm{mg} / \mathrm{ml})$ was bought from Brenntag (Denmark). Casein, EDC, and Ethanolamine were obtained from Sigma Aldrich (USA). HRP-conjugated donkey anti-horse IgG was purchased from Jackson ImmunoResearch (USA). Neuro-2a cells (CCL-131) were purchased from ATCC (USA). MEM media, FBS, and antibiotics were bought from GE Healthcare Life Sciences/Hyclone (USA). Botulinum antitoxin equine type A (standard antitoxin) was bought from NIBSC (UK). RIPA buffer was obtained from GenDEPOT (USA). Anti-SNAP-25 was purchased from Biolegend (USA). BCA protein kit and Goat-anti 
mouse HRP were purchased from Thermo Fisher Scientific (USA), and PierceTM F(ab')2 Preparation Kit, and Sulfo-NHS buffer were also purchased from Thermo Fisher Scientific (USA). Western LightingTM PLUS-ECL was bought from PerkinElmer (USA). MabSelect SuRe resin was bought from GE Healthcare Life Sciences (USA). BoNT/A1 was prepared by the Agency for Defense Development in South Korea.

\section{Production of the BoNT/A1-HCR}

The amino acid sequences of BoNT/A1 were obtained from the ExPASy, a bioinformatics resource portal (P10845). Full-length BoNT/A1-HCR gene (amino acid 876 through 1296) was chemically synthesized (Bioneer, South Korea), and cloned into the pET-28a vector. The BoNT/A1-HCR gene-containing plasmid was transformed into the E. coli BL21(DE3) cells. When $\mathrm{OD}_{600}$ of the $E$. coli culture reached $0.6 \pm 0.1$, the cells were induced with 1 $\mathrm{mM}$ isopropyl- $\beta$-D-thiogalactopyranoside (IPTG) for $6 \mathrm{~h}$ at $30^{\circ} \mathrm{C}$. The cells were harvested by centrifugation at $4,000 \times g$ for $20 \mathrm{~min}$, and resuspended in lysis buffer $(50 \mathrm{mM}$ sodium phosphate, 300 $\mathrm{mM} \mathrm{NaCl}$, and $10 \mathrm{mM}$ imidazole, $\mathrm{pH}$ 8.0). BoNT/A1-HCR was purified using the His-tagged protein purification protocol, as described previously [32]. Complete cell lysis was achieved by sonication, and the lysate was treated with $5 \mu \mathrm{g} / \mathrm{ml}$ DNase I. Cell debris was removed by centrifugation at $10,000 \times g$ for $30 \mathrm{~min}$. The supernatants were filtered through a $0.45 \mu \mathrm{m}$ MF membrane filter, and applied to a Ni-NTA resin column for $1 \mathrm{~h}$ at $4^{\circ} \mathrm{C}$. Then, the column was washed with washing buffer $(50 \mathrm{mM}$ sodium

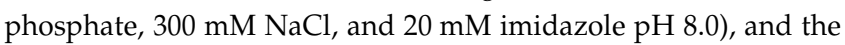
resin-bound BoNT/A1-HCR was eluted by addition of elution buffer increasing concentrations of imidazole (30-250 mM). The eluted protein was analyzed on a $12 \%$ SDS-PAGE, and dialyzed overnight with PBS at $4^{\circ} \mathrm{C}$ to remove imidazole. Dialyzed BoNT/ A1-HCR protein was treated with thrombin (10 units/1 mg) for $12 \mathrm{~h}$ at $4^{\circ} \mathrm{C}$. Cleaved protein was purified by a Ni-NTA resin packed affinity chromatography column. Flow through, $20 \mathrm{mM}$, and $30 \mathrm{mM}$ eluted fractions were dialyzed with PBS overnight at $4^{\circ} \mathrm{C}$. Protein concentration was determined by the BCA protein kit.

The purity of BoNT/A1-HCR was analyzed by reverse-phase HPLC (Agilent 1260 Infinity II HPLC System, Agilent, USA). The $600 \mu \mathrm{g}$ sample was injected into the $4.6 \times 250 \mathrm{~mm} \mathrm{C} 4$ column (VyDAC, USA). The protein was eluted from the column using a linear gradient from $0 \%$ buffer A $(0.1 \%$ TFA) to $100 \%$ buffer $\mathrm{B}$ ( $100 \%$ acetonitrile, $0.1 \%$ TFA). The separation was performed at ambient temperature, $1 \mathrm{ml} / \mathrm{min}$, and was monitored at a wavelength of $280 \mathrm{~nm}$. The peaks in the chromatogram were integrated, and area under the BoNT/A1-HCR peak was reported as the percentage of the total area under all peaks.

\section{Immunization of Mice and Rabbits Using BoNT/A1-HCR}

Six-week-old female Balb/c mice $(n=5)$ were immunized with the BoNT/A1-HCR. For vaccination, BoNT/A1-HCR (the antigen) was dissolved in PBS, and emulsified in $2 \%$ alhydrogel adjuvant in a 1:1 proportion. Mice were intramuscularly injected with
$100 \mu \mathrm{l}$ of emulsion containing $10 \mu \mathrm{g}$ of BoNT/A-HCR three times at two-week intervals. The control group mice $(n=5)$ received the adjuvant only.

Two female New Zealand white rabbits (Doo Yeol Biotech., Korea) weighing 2-3 kg were intramuscularly administered $300 \mu \mathrm{g}$ of the BoNT/A1-HCR in $100 \mu$ of PBS (pH 7.4) emulsified with $100 \mu \mathrm{l}$ of Freund's Complete Adjuvant (FCA) at week 0. Subsequently, the rabbits were injected intramuscularly with the same volume of BoNT/A1-HCR antigen emulsified with $100 \mu \mathrm{l}$ of Freund's Incomplete Adjuvant (FIA) five times every two weeks. Approximately $50 \mu \mathrm{l}$ mouse blood was collected by retro-orbital bleeding after anesthesia using Ketamine $(100 \mathrm{mg} / \mathrm{kg})$ and Xylazine $(10 \mathrm{mg} / \mathrm{kg})$, and also about $200 \mu \mathrm{l}$ of rabbit blood was collected from the marginal ear vein. The collected blood was separated and serum was stored at $-20^{\circ} \mathrm{C}$ until further use. The Institutional Animal Care and Use Committee of the Agency for Defense Development approved the mouse and rabbit experiments (ADD-IACUC-15-21).

\section{Mouse and Rabbit Antibody Titer Determination Using ELISA}

The anti-BoNT/A1-HCR antibodies in the sera of mice or rabbits were measured by indirect ELISA. Microplates were coated with the BoNT/A1-HCR protein $(0.5 \mu \mathrm{g} / \mathrm{ml})$ in PBS and incubated for $1 \mathrm{~h}$ at $37^{\circ} \mathrm{C}$. Next, the plates were washed with the washing buffer $(0.1 \%$ Tween 20-containing PBS), and blocked with 1\% BSA-containing PBS. Serum samples diluted from 1:100 to $1: 6,400$ with two-fold serial dilutions in the blocking buffer (100 $\mu \mathrm{l} /$ well) were added to the plates. After $1 \mathrm{~h}$ incubation at $37^{\circ} \mathrm{C}$, each well was washed four times with washing buffer. The goat anti-mouse IgG antibody or goat anti-rabbit IgG antibody was diluted $(1: 2,000)$ in the blocking buffer, added to each well $(100 \mu \mathrm{l} /$ well), and incubated for $30 \mathrm{~min}$. Following the washing step, the plates were treated with $100 \mu \mathrm{l} /$ well of $3,3^{\prime}, 5,5^{\prime}$ tetramethylbenzidine (TMB) solution (substrate) for $30 \mathrm{~min}$ in the dark at $25^{\circ} \mathrm{C}$. The reaction was stopped by adding $100 \mu \mathrm{l} /$ well of $1 \mathrm{~N} \mathrm{H}_{2} \mathrm{SO}_{4}$, and the absorbance of the reaction products was measured at $\mathrm{OD}_{450}$. The endpoint of titration was determined as described previously [29]. For calculation of endpoint titer, the optimum cut-off value for this method was determined by calculating the average absorbance values of negative control sera of mouse or rabbit. The negative control sample in mouse titer analysis was the serum from mice injected with only adjuvant, and that of rabbits was the pre-immune serum. The background absorbance values of pre-immune serum from mice and rabbits were 0.3 and 0.15 , respectively. Therefore, we set the cut-off value to 0.3 , and immune serum titers were calculated using the highest sample dilution with an $\mathrm{OD}_{450}$ reading greater than 0.3.

\section{Vaccination of Horse Using BoNT/A1-HCR}

A five-year-old female Halla horse weighing 200-300 kg served as the experimental animal, and the animal was maintained under the supervision of a veterinarian, according to the Guidance of Livestock Production announced by the Ministry of Food and 
Drug Safety (MFDS 2016-110). The Halla horse was immunized with the BoNT/A1-HCR antigen, and aluminum hydroxide gel $(0.6 \mathrm{mg} / \mathrm{ml})$ was used as the adjuvant. The adjuvant was mixed with $3 \mathrm{mg}$ of BoNT/A1-HCR antigen in a 1:1 ratio, to achieve a final concentration of $1 \mathrm{mg} / \mathrm{ml}$, and $3 \mathrm{ml}$ of this mixture was injected to the Halla horse. The antigen was injected three times at 2-week intervals, followed by four times at $4-5$ week intervals. Injection was performed subcutaneously on the right side of the cervix, and blood for assay was collected from the left jugular vein before vaccination. The blood sample was allowed to be coagulated naturally in a conical tube, and the serum was separated by centrifugation. The Halla horse experiment was performed following the protocols approved by the Institutional Animal Care and Use Committee (IACUC) of Jeju National University (Jeju, Republic of Korea), where the animal experiment was conducted (Approval ID: 2015-0008).

\section{Horse Antibody Titer Determination Using ELISA}

To develop and optimize an indirect ELISA protocol for titration of the anti-BoNT/A1-HCR antibodies in horse serum, dilution factor for the HRP-conjugated anti-horse IgG, reaction time, temperature of samples/antibodies, and washing steps were optimized. For coating wells with antigen, microplates (Corning Inc., NY, USA) were incubated with $100 \mu \mathrm{l}$ of antigen-containing carbonate-bicarbonate buffer $(1 \mu \mathrm{g} / \mathrm{ml}, \mathrm{pH} 9.6)$ for $16 \mathrm{~h}$ at $25^{\circ} \mathrm{C}$. The plates were blocked with blocking buffer (PBS containing 1\% casein). The $100 \mu$ l serum samples, diluted from 1:100 to 1:6,400 with two-fold serial dilutions in the blocking buffer, were added to the plates, incubated for $1 \mathrm{~h}$ at $37^{\circ} \mathrm{C}$, and subsequently washed five times with the $300 \mu \mathrm{l} /$ well of washing buffer (PBS containing $0.5 \%$ Tween 20). The HRP-conjugated donkey anti-horse IgG was diluted $(1: 30,000)$ with the blocking buffer, added to each well with $100 \mu \mathrm{l}$, and incubated for $30 \mathrm{~min}$ at $37^{\circ} \mathrm{C}$. Following washing, $100 \mu \mathrm{l} /$ well of TMB solution was added to the samples and incubated for $30 \mathrm{~min}$ in the dark at RT. The reaction was stopped by adding $100 \mu \mathrm{l}$ /well of $1 \mathrm{~N} \mathrm{H}_{2} \mathrm{SO}_{4}$, and the absorbance of the reaction products was measured at $\mathrm{OD}_{450}$. For titration, the optimum cut-off value for this method was determined by calculating the average absorbance values of pre-immune horse serum. The optimum cut-off value was 0.15 and the titer was calculated from the highest dilution of sample with an $\mathrm{OD}_{450}$ reading of greater than 0.15 [29].

\section{In Vitro Neutralization Assay against BoNT/A1 Toxin}

The BoNT/A1 toxin neutralizing efficacy was evaluated by estimating the cleavage of SNAP-25 in the Neuro-2a cells [33, 34]. The Neuro-2a cells were seeded at a density of $1 \times 10^{5}$ cells/well in a 24 -well plate with MEM media (10\% FBS, $1 \%$ antibiotics). The cells were treated with $50 \mu \mathrm{g} / \mathrm{ml}$ ganglioside for $24 \mathrm{~h}$. After the treatment of ganglioside, the cells were changed with toxin and equine serum diluted MEM media. Four hundred microliters of $20 \mu \mathrm{g} / \mathrm{ml}$ BoNT $/ \mathrm{A} 1$ toxin $\left(1.75 \times 10^{5} \mathrm{LD}_{50} / \mathrm{ml}\right)$ and equine serum at varying concentrations were diluted in MEM media (10\% FBS,
$1 \%$ antibiotics), and incubated for $1 \mathrm{~h}$ at $37^{\circ} \mathrm{C}$. After the incubation, the toxin and equine serum diluted media were added to the cells. Neuro-2a cells treated with the toxin and equine serum samples were cultured for 2 days, and the cells were harvested for western blot analysis. The cells were centrifuged at $4,000 \times g$ for $5 \mathrm{~min}$, washed with fresh PBS, and the harvested cells were lysed using RIPA buffer for $30 \mathrm{~min}$ at $4^{\circ} \mathrm{C}$. After the incubation, the lysed cells were centrifuged at $13,000 \times g, 4^{\circ} \mathrm{C}$ for $30 \mathrm{~min}$, and the supernatants were collected. Next, $3 \mu \mathrm{g}$ of whole cell lysate was loaded onto a $12 \%$ polyacrylamide gel, and transferred to nitrocellulose membrane by electroblotting. The membrane was blocked with $6 \%$ skim milk, and then washed with washing buffer ( $0.1 \%$ Tween 20-containing TBS). After washing, the membrane was incubated with the anti-SNAP-25 or anti-betaactin at a 1:5,000 dillution for $1 \mathrm{~h}$ at $25^{\circ} \mathrm{C}$. Membranes were then washed and hybridized with the HRP-conjugated goat anti-mouse IgG antibodies at 1 1:5,000 dilution for $1 \mathrm{~h}$ at $25^{\circ} \mathrm{C}$. After additional washing of membranes, the bound antibody was detected with Western Lighting PLUS-ECL. For SNAP-25 cleavage assay, the negative controls were untreated Neuro-2A cells and Neuro-2A cells treated with $20 \mu \mathrm{g} / \mathrm{ml}\left(1.7 \times 10^{5} \mathrm{LD}_{50} / \mathrm{ml}\right)$ BoNT/ A1 toxin. Standard antitoxin was used as the positive control.

\section{Preparation of $\mathrm{F}\left(\mathrm{ab}^{\prime}\right) 2$}

Saturated ammonium sulfate solution $\left(4.1 \mathrm{M}, 25^{\circ} \mathrm{C}\right)$ was slowly added to $20 \mathrm{ml}$ of horse serum until the concentration in the solution reached $70 \%$, while the temperature was maintained to $4^{\circ} \mathrm{C}$. Precipitated protein was separated through centrifugation at $4^{\circ} \mathrm{C}, 5,000 \times g$, for $30 \mathrm{~min}$. Subsequently, the pellet was resuspended in MabSelect SuRe resin buffer A (20 mM sodium phosphate, $150 \mathrm{mM} \mathrm{NaCl}, \mathrm{pH}$ 7.2), bound to MabSelect SuRe resin, washed in 5 column volumes of buffer $\mathrm{A}$, and eluted in 10 column volumes of $100 \%$ buffer B (0.1 M sodium citrate, $\mathrm{pH} 3.0)$ in a linear gradient. Before the elution, the tube in which the elution fraction would be collected was prepared by placing $1.0 \mathrm{M}$ Tris- $\mathrm{HCl}(\mathrm{pH}$ 8.0) for one-tenth of the elution volume. The elution fraction buffer was changed to pepsin digestion buffer (20 mM sodium acetate, $\mathrm{pH} 4.0)$, and pepsin treatment was conducted. $\mathrm{F}\left(\mathrm{ab}^{\prime}\right) 2$ was prepared using a Pierce $\mathrm{F}\left(\mathrm{ab}^{\prime}\right) 2$ Preparation Kit according to the manufacturer's instructions. To determine the extent of digestion and confirm the presence and purity of $F\left(a b^{\prime}\right) 2$, the purified $\mathrm{F}\left(\mathrm{ab}^{\prime}\right) 2$ was analyzed on a $8 \%$ SDS-PAGE under non-reducing conditions. The $\mathrm{F}\left(\mathrm{ab}^{\prime}\right) 2$ was dialyzed for $12 \mathrm{~h}$ at $4^{\circ} \mathrm{C}$ with PBS (pH 7.4) and then concentrated by Viva-spin. The final product was stored at $-80^{\circ} \mathrm{C}$ until use.

\section{Affinity Measurements of $\mathrm{F}\left(\mathrm{ab}^{\prime}\right) \mathbf{2}$}

Affinity studies of the purified $\mathrm{F}\left(\mathrm{ab}^{\prime}\right) 2$ were carried out using biolayer interferometry by the Octet Red System (Pall ForteBio LCC, USA). All steps were performed at $30^{\circ} \mathrm{C}$ with shaking at $1,500 \mathrm{rpm}$ in a 96 -well plate containing $200 \mu \mathrm{l}$ per well. Aminereactive second generation biosensors were activated by the EDC and sulfo-NHS buffer. The $10 \mu \mathrm{g} / \mathrm{ml}$ of ligand, BoNT/A1-HCR, 
was loaded into the activated Amine Reactive 2nd Generation (AR2G) Biosensor which was then moved to the quenching step. After the quenching in the ethanolamine, the ligand-loaded biosensor reacted with the purified equine $F\left(a^{\prime}\right) 2$ concentration dependently $(0.32,8,40,200$, and 1,000 nM). The ligand-loaded biosensors were in the association step about $300 \mathrm{sec}$, and it moved to the dissociation step. Association and dissociation were measured as changes over time in light interference, and curves are presented after subtraction of parallel measurements from unloaded biosensors. The data fitting and $K_{D}$ value were analyzed by the Data Analysis 9.0 program supplied by Pall ForteBio. For the data fitting, a heterogeneous ligand model was used.

\section{In Vivo Protection Assay}

A bioassay using mice was performed to evaluate the in vivo protection by BoNT/A1 toxin, as described previously [35]. Briefly, $0.1 \mathrm{ml}$ of the BoNT/A1 toxin mixture $\left(1 \mathrm{LD}_{50}=0.114 \mathrm{ng}\right.$ / mouse, $1.14 \mu \mathrm{g} / 0.1 \mathrm{ml}$ ) was prepared for $10,000 \mathrm{LD}_{50}$ assays with PBS ( $\mathrm{pH} 7.4$ ), and the pre-immune serum was used as the negative control. Next, $0.1 \mathrm{ml}$ of toxin neutralization assay samples were prepared by mixing $10,000 \mathrm{LD}_{50}$ of toxin with $10 \%$ equine BoNT/ A1 serum or purified $\mathrm{F}\left(\mathrm{ab}^{\prime}\right) 2$ in $\mathrm{PBS}$ ( $\mathrm{pH} 7.4$ ), and the toxin and antitoxin mixture was incubated for $1.5 \mathrm{~h}$ at room temperature. For the calculation of the amounts of $1 \mathrm{IU}$ of the purified $\mathrm{F}\left(\mathrm{ab}^{\prime}\right) 2$,
$\mathrm{F}\left(\mathrm{ab}^{\prime}\right) 2$ was prepared in a dose step-down manner $(500,300$, and $100 \mu \mathrm{g} /$ mouse) and was mixed with $10,000 \mathrm{LD}_{50}$ BoNT/A1 toxin. After completion of the incubation, the incubation samples were administered into Balb/c mice ( $n=5-6 /$ group) with intraperitoneal injection and mice were monitored for seven days for intoxication symptoms or death after the injection. All animal experiments were performed following the protocols approved by the Institutional Animal Care and Use Committee (IACUC) of the Agency of Defense Development, where the animal experiments were conducted (approval ID: ADD-IACUC-16-05/ADD-IACUC16-28).

\section{Results}

\section{Preparation of BoNT/A1-HCR and Immunization of Mice and Rabbits}

Recombinant BoNT/A1-HCR, amino acid 876 through 1296 was expressed as a N-terminal His-tagged fusion protein in E. coli BL21(DE3) [36]. After thrombin cleavage of the His-tag, recombinant BoNT/A1-HCR was confirmed by the presence of a protein with the expected molecular weight $(50 \mathrm{kDa})$ using SDS-PAGE followed by Coomassie blue staining (Fig. 1B). To confirm the purity of BoNT/A1-

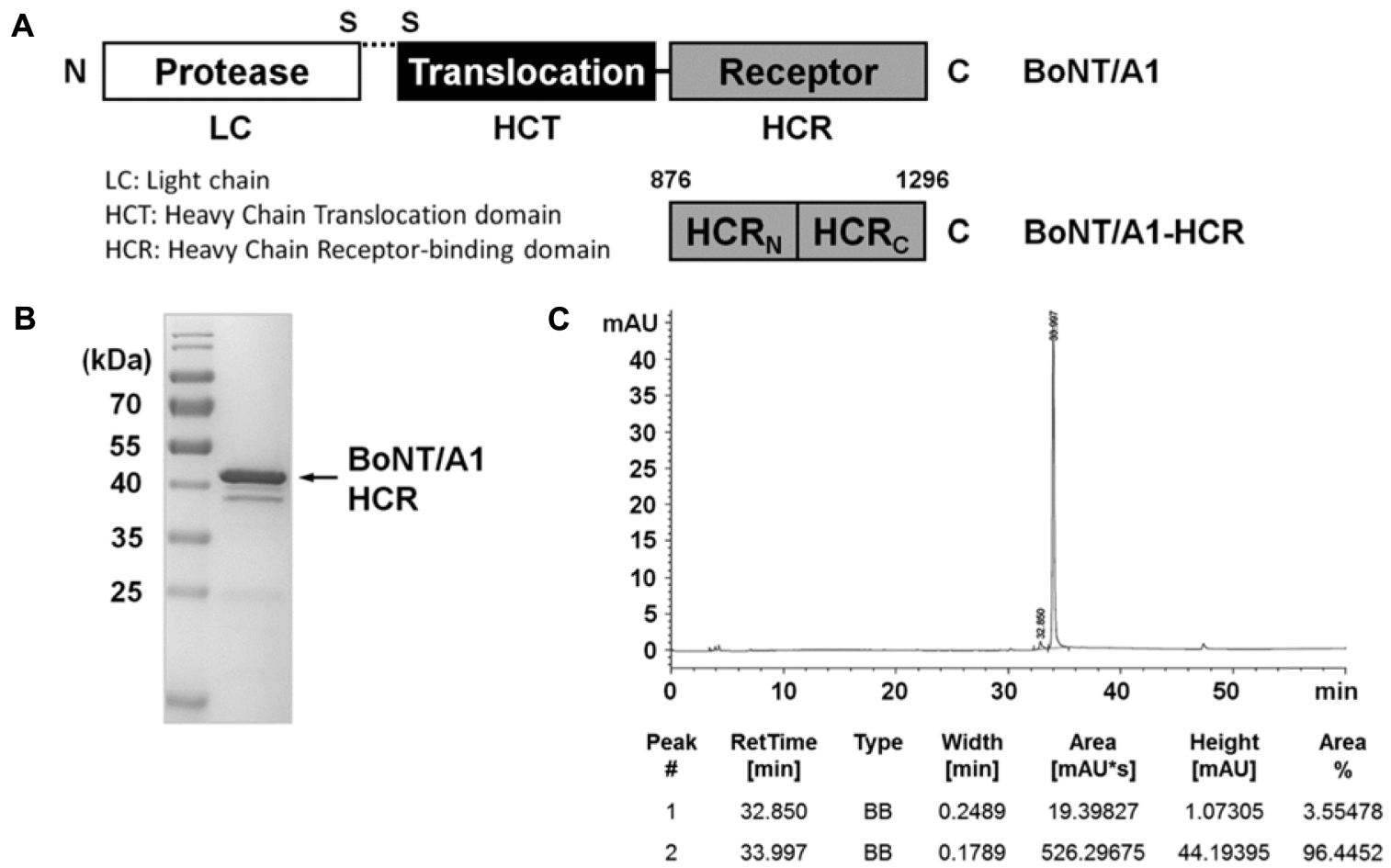

Fig. 1. Purity analysis of the purified BoNT/A1-HCR.

The proteins were purified using Ni-NTA resin and the His-tag was removed using thrombin. (A) A schematic diagram of BoNT/A1 and BoNT/ A1-HCR. (B) SDS-PAGE analysis of the purified BoNT/A1-HCR. Lane 1, standard molecular-weight markers; lane 2, BoNT/A1-HCR (10 $\mu \mathrm{g})$ under reducing conditions. (C) Reverse phase-HPLC analysis. BoNT/A1-HCR (30 $\mu \mathrm{g})$ was analyzed on the C4 column. Detection was performed at OD280. 

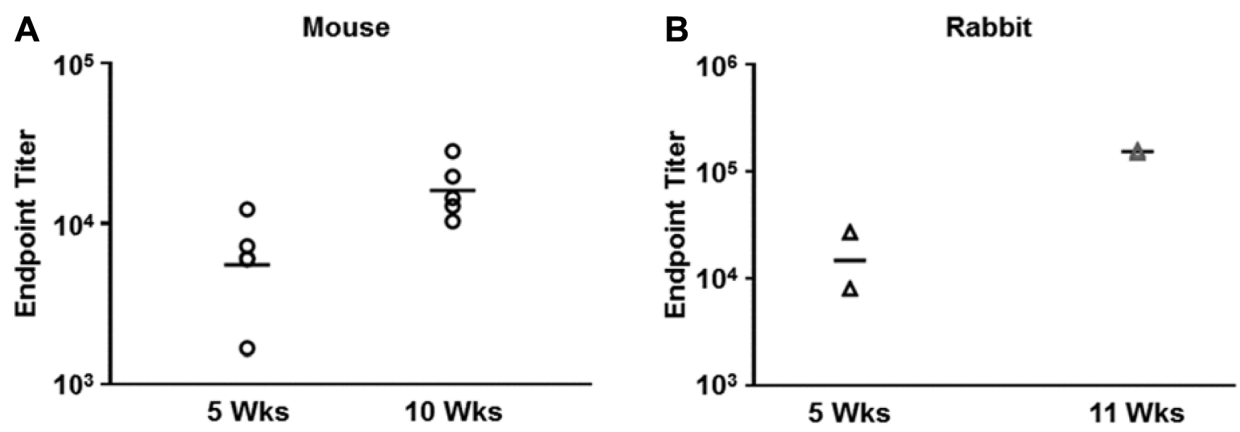

Fig. 2. BoNT/A1-HCR-specific antibody titer in mice (A) and rabbits (B).

Mice ( $n=5$ /group) and rabbits $(n=2$ /group) were immunized three times, and six times, respectively. Serum samples from immunized animals were collected at different time points, and the specific responses of anti-BoNT/A1-HCR antibody were assayed by ELISA. Antibody level from each animal is presented as endpoint titers in ELISA, and symbols showed individual values. The bars represent geometric mean titers of each group.

HCR, reverse-phase HPLC analysis was performed using a C4 column. The peak of BoNT/A1-HCR was observed at 33.9-min retention time. The result from reverse-phase HPLC analysis indicated that the purified BoNT/A1-HCR had $96 \%$ purity (Fig. 1C).

To analyze the immune response-inducing ability of BoNT / A1-HCR, we applied our BoNT/A1-HCR to Balb/c mice ( $n=5 /$ group), and rabbits $(n=2 /$ group). In this analysis, the titers of anti-BoNT/A1-HCR IgG in serum from BoNT/A1-HCR-immunized mice and rabbits were time-dependently increased, and remained high until 10 weeks for mice (Fig. 2A) and 11 weeks for rabbits (Fig. 2B). However, no anti-BoNT/A1-HCR IgG was detected in any adjuvant-treated control animals (data not shown).

These data indicated that our BoNT/A1-HCR could induce BoNT/A1-HCR-specific antibodies in mice and rabbits.

\section{Immunization of Halla Horse with BoNT/A-HCR}

Before immunization, the hematological parameters of Halla horses were evaluated to assess their clinical health and suitability for immunization (data not shown). Subsequently, the horses were injected with the BoNT/A1HCR antigen according to the immunization schedule. After immunization, equine serum sample was collected at different time points over 24 weeks, and the antibody titer against BoNT/A1-HCR was measured using indirect ELISA. The titer increased rapidly on week 4 , and remained close to 1,000 for the next 20 weeks (Table 1). In order to test the boosting effects of additional vaccination, we monitored the changes in antibody titers after administration of the boosts. The titers of weeks 13 and 22 decreased compared to those observed after the previous injections, since immunization was not performed on week 10 or 20 . The antibody titers increased after additional boost vaccination; however, the titers did not increase to the level observed at week 4. These data indicated that BoNT/A1-HCR injection in Halla horse induced an immune response with antibody production.

\section{In Vitro Neutralizing Efficacy of BoNT/A1 Antitoxin}

The neutralizing efficacy of the week 24 serum from the immunized horse was evaluated in vitro using the SNAP25 protein cleavage assay and the Neuro-2a cells. Standard antitoxin was used as the standard for comparison of the neutralizing efficacy of the experimental serum. The reported data showed that one international unit (IU) of the standard antitoxin neutralized approximately 10,000 intraperitoneal mouse $\mathrm{LD}_{50}$ of the BoNT/A1 toxin $[35,37]$. The 1:1 ratio of cleaved and uncleaved SNAP25 was found

Table 1. The vaccination schedules of BoNT/A1-HCR to Halla horse and the titer of horse serum after 24 weeks of immunization.

\begin{tabular}{cccc}
\hline Week & Blood collection & Vaccination & Antibody titer \\
\hline 0 & $\bigcirc$ & $\bigcirc$ & 0 \\
2 & $\bigcirc$ & $\bigcirc$ & 635 \\
4 & $\bigcirc$ & $\bigcirc$ & 1,420 \\
8 & $\bigcirc$ & $\bigcirc$ & 1,130 \\
10 & $\bigcirc$ & - & 1,035 \\
13 & $\bigcirc$ & 0 & 876 \\
18 & $\bigcirc$ & 0 & 798 \\
20 & 0 & - & 1,016 \\
22 & 0 & 0 & 898 \\
24 & 0 & 0 & 1,108 \\
\hline
\end{tabular}


A

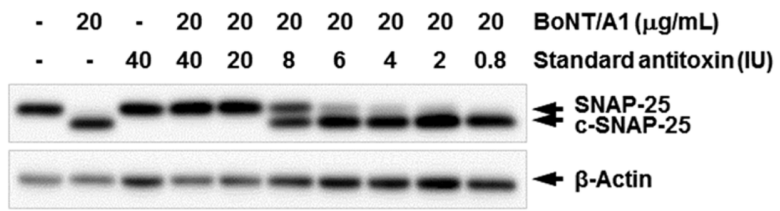

B

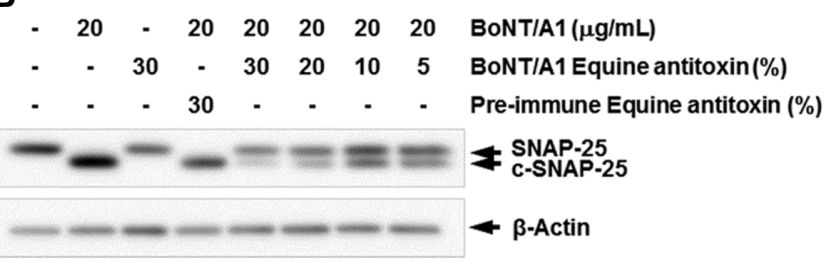

Fig. 3. In vitro neutralizing assay for BoNT/A1 antitoxin.

The Neuro-2a cells were seeded at a density of $1 \times 10^{5}$ cells/well in a 24-well plate. The cultured cells were treated with ganglioside for 1 day. Then, the culture medium was changed into the indicated BoNT/A1 and standard antitoxin (A) or equine anti-toxin-containing media (B). Before treating cells, the mixtures of BoNT/A1 and standard antitoxin or equine antitoxin were incubated for $1 \mathrm{~h}$ at $37^{\circ} \mathrm{C}$. After two days of treatment, cells were collected and analyzed by western blot. (A) Inhibition of BoNT / A1-mediated SNAP-25 cleavage by co-incubation with $20 \mu \mathrm{g} / \mathrm{ml}$ of standard antitoxin. (B) Inhibition of BoNT/A1-mediated SNAP-25 cleavage during co-incubation with BoNT/A1-HCR-immunized equine serum.

in the $8 \mathrm{IU}$ standard antitoxin treatments. The $20 \mu \mathrm{g} / \mathrm{ml}$ BoNT/A1 toxins were neutralized completely in the $20 \mathrm{IU}$ standard antitoxin treatments (Fig. 3A). To test the in vitro neutralizing efficacy of our BoNT/A1-HCR equine serum, BoNT/A1 toxin $(20 \mu \mathrm{g} / \mathrm{ml})$ and equine serum at various concentrations were mixed and allowed to react. The Neuro-2a cells were treated with the pre-incubated mixture and the protective effect of the mixture against SNAP-25 protein cleavage was examined. Cleavage of SNAP-25 protein decreased with the increasing concentration of equine serum, which suggested neutralization of the BoNT/A1 toxin by the BoNT/A1-HCR equine serum (Fig. $3 \mathrm{~B})$. It was estimated that a 5\% BoNT/A1 equine antitoxin (20 $\mu \mathrm{l}$ serum $/ 400 \mu \mathrm{l}$ reaction sample) had an in vitro neutralizing activity of $>8$ IU.

\section{Characterization of Purified $\mathrm{F}\left(\mathrm{ab}^{\prime}\right) 2$ as Antitoxin}

To obtain $\mathrm{F}\left(\mathrm{ab}^{\prime}\right) 2$ from the immunized horse serum, 70\% ammonium sulfate precipitation was performed, followed by total IgG purification using affinity chromatography with MabSelect SuRe resin. Purified IgG was fragmented to $\mathrm{F}\left(\mathrm{ab}^{\prime}\right) 2$ by pepsin digestion (Fig. $4 \mathrm{~A}$ ). In order to determine the $\mathrm{F}\left(\mathrm{ab}^{\prime}\right)$ 2-binding affinity of BoNT/A1-HCR, the affinity constant $\left(\mathrm{K}_{\mathrm{D}}\right)$ for antibodies binding to BoNT/A1-HCR was measured (Fig. 4B). BoNT/A1-HCR was loaded on a biosensor and the various concentrations of $\mathrm{F}\left(\mathrm{ab}^{\prime}\right) 2$ were reacted with the BoNT/A1-HCR-loaded biosensor. Kinetic measurements were done through association $\left(\mathrm{K}_{\mathrm{on}}\right)$ and dissociation $\left(K_{\text {off }}\right)$ rate constants of $F\left(a b^{\prime}\right) 2$ [38-40]. The $K_{D}$ value of $\mathrm{F}\left(\mathrm{ab}^{\prime}\right)_{2}$ was determined from the ratio of $\mathrm{K}_{\text {off }} / \mathrm{K}_{\mathrm{on}}$,
A

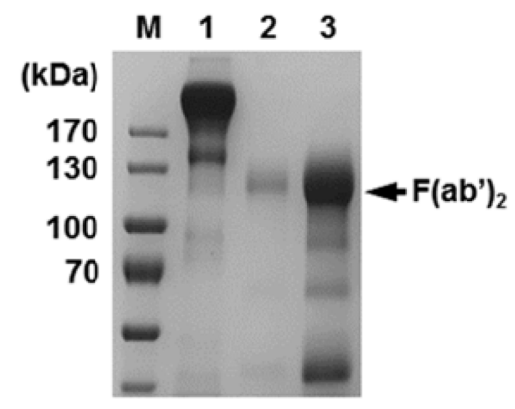

B $\mathrm{nm}$

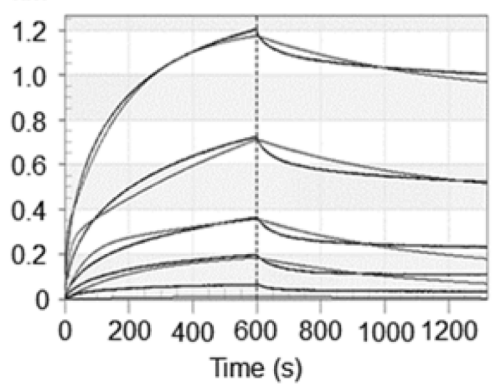

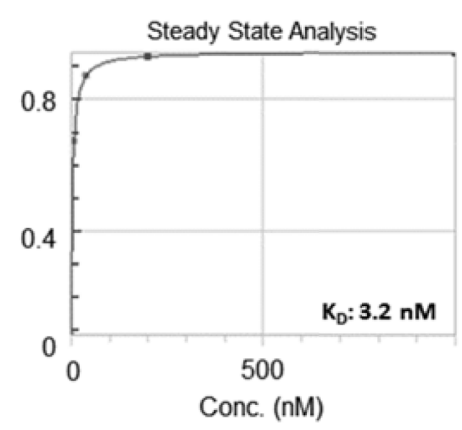

C

Kinetic analysis of ligands to esBA $\mathrm{F}\left(\mathrm{ab} \mathrm{b}^{\prime}\right)_{2}$ interaction (Conc. Range: $1 \mu \mathrm{M}$ to $0.32 \mathrm{nM}$ )

\begin{tabular}{|c|c|c|c|c|c|c|c|c|c|c|c|c|c|}
\hline \multirow{2}{*}{ Model } & \multicolumn{2}{|c|}{$K_{1 f w d}$} & \multicolumn{2}{|c|}{$\mathrm{K}_{1 \mathrm{rev}}$} & \multicolumn{2}{|c|}{$K_{1 D}$} & \multicolumn{2}{|c|}{$K_{2 f w d}$} & \multicolumn{2}{|c|}{$\mathrm{K}_{2 \mathrm{rev}}$} & \multicolumn{2}{|c|}{$\mathrm{K}_{2 \mathrm{D}}$} & \multirow{2}{*}{$\mathbf{R}^{2}$} \\
\hline & {$[1 / \mathrm{M} \cdot \mathrm{S}]$} & est.error & {$[1 / \mathrm{S}]$} & est.error & [nM] & est.error & {$[1 / \mathrm{M} \cdot \mathrm{S}]$} & est.error & {$[1 / \mathrm{S}]$} & est.error & [nM] & est.error & \\
\hline $\begin{array}{l}\text { Heterogenous } \\
\text { ligand model }\end{array}$ & $5.35 E+03$ & $2.93 \mathrm{E}+01$ & $1.78 \mathrm{E}-05$ & $5.58 \mathrm{E}-06$ & 3.19 & 3.33E-03 & $3.71 E+05$ & $7.10 E+03$ & $1.78 \mathrm{E}-03$ & $2.37 \mathrm{E}-15$ & 4.79 & $1.12 \mathrm{E}-01$ & 0.9931 \\
\hline
\end{tabular}

Fig. 4. Purification of $\mathrm{F}\left(\mathrm{ab}^{\prime}\right)_{2}$ from BoNT/A1-HCR-immunized equine serum and in vitro binding affinity analysis for purified $\left.\mathrm{F}(\mathrm{ab})_{2}\right)_{2}$. (A) The samples were analyzed with 10\% SDS-PAGE under non-reducing conditions. Lane 1, purified IgG before the pepsin treatments; lane 2, wash fraction after the pepsin treatments; lane 3, final $\mathrm{F}\left(\mathrm{ab}^{\prime}\right)_{2}$ purification product. (B) In vitro binding affinity was analyzed by Octet Red 384 . The kinetics of association and dissociation for $0.32,8,40,200$, and $1,000 \mathrm{nM}$ of $\mathrm{F}\left(\mathrm{ab}^{\prime}\right)_{2}$ to BoNT/A1-HCR $(10 \mu \mathrm{g} / \mathrm{ml})$. The $\mathrm{Y}$ axis indicates the changes in wavelength depending on ligand and analyte binding. $K_{\mathrm{D}}$ value was $3.2 \mathrm{nM}$ in steady-state analysis. 
Table 2. In vivo protection of BoNT/A1-HCR antitoxin.

\begin{tabular}{ccccc}
\hline \multicolumn{5}{c}{ Numbers of survived mice (\%) } \\
\hline \multirow{2}{*}{ Control $^{\mathrm{a}}$} & BoNT/A1-HCR serum $^{\mathrm{b}}$ & $\mathrm{F}\left(\mathrm{ab}^{\prime}\right)_{2}$ & $\mathrm{~F}\left(\mathrm{ab}^{\prime}\right)_{2}$ & $\mathrm{~F}(\mathrm{ab})_{2}$ \\
& $5 / 5(100)$ & $(500 \mu \mathrm{g} / \mathrm{mouse})^{\mathrm{c}}$ & $(300 \mu \mathrm{g} / \text { mouse })^{\mathrm{c}}$ & $\left(100 \mu \mathrm{g} / \mathrm{mouse}^{\mathrm{c}}\right.$ \\
\hline $0 / 5(0)$ & $6 / 6(100)$ & $5 / 5(100)$ & $6 / 6(100)$ \\
\hline
\end{tabular}

${ }^{\mathrm{a}} 10 \%$ pre-immune equine serum was incubated with $10,000 \mathrm{LD}_{50}$ toxin.

${ }^{\mathrm{b}} 10 \%$ BoNT/A1-HCR-immunized equine serum at 24 weeks with $10,000 \mathrm{LD}_{50}$ toxin.

${ }^{\mathrm{c}}$ The purified $\mathrm{F}\left(\mathrm{ab}^{\prime}\right)_{2}$ from BoNT/A1-HCR-immunized equine serum at 24 weeks with $10,000 \mathrm{LD}_{50}$ toxin.

and results showed the best fits using the heterogeneous ligand model. The values of $\mathrm{K}_{\mathrm{D} 1}$ and $\mathrm{K}_{\mathrm{D} 2}$ were $3.16 \mathrm{nM}$ and $4.79 \mathrm{nM}$, respectively. $\mathrm{K}_{\text {on }}$ and $\mathrm{K}_{\text {off }}$ values were shown in Fig. 4C.

\section{In Vivo Neutralizing Efficacy of the BoNT/A Antitoxin}

To evaluate the in vivo neutralizing efficacy, the BoNT/ A1 toxin $\left(10,000 \mathrm{LD}_{50}\right)$, and equine serum immunized with BoNT/A1-HCR at 24 weeks $(10 \%$ dilution in $200 \mu \mathrm{l})$ or $\mathrm{F}\left(\mathrm{ab}^{\prime}\right) 2$ (500 $\mu \mathrm{g} /$ mouse) were mixed, and incubated for $1.5 \mathrm{~h}$ at room temperature. Next, the mixture was administered intraperitoneally to mice, and lethality was recorded for seven days. The control group was injected with preimmune equine serum. All the mice was injected with BoNT/A1-HCR-immunized serum or F(ab')2 survived and showed normal behavior. In particular, $500 \mu \mathrm{g}$ of the purified $\mathrm{F}\left(\mathrm{ab}^{\prime}\right) 2$ antitoxin protected mice exposed to 10,000 $\mathrm{LD}_{50}$ of BoNT/A1 toxin. To calculate the amounts of $1 \mathrm{IU}$ of the purified $\mathrm{F}\left(\mathrm{ab} \mathrm{b}^{\prime}\right) 2$, the mice were injected with $\mathrm{F}\left(\mathrm{ab} \mathrm{b}^{\prime}\right) 2$ in a dose step-down manner (500, 300, and $100 \mu \mathrm{g} /$ mouse). The results showed that the group injected with $100 \mu \mathrm{g} \mathrm{F}\left(\mathrm{ab}^{\prime}\right) 2$ was resistant against the $10,000 \mathrm{LD}_{50}$, and that the $100 \mu \mathrm{g}$ purified $\mathrm{F}\left(\mathrm{ab}^{\prime}\right) 2$ had above 1 IU activity in mice (Table 2). As expected, all the mice in the control group died within $24 \mathrm{~h}$ of the toxin challenge. These results demonstrated that the Halla horses immunized with BoNT/A1-HCR produced protective IgG antibodies against BoNT/A1, and the final antitoxin products of $\mathrm{F}\left(\mathrm{ab}^{\prime}\right) 2$ had in vivo neutralizing activities.

\section{Discussion}

Antitoxins derived from the sera of hyperimmunized horses have a long history [41-43], and have been used for neutralizing toxins from microorganisms. In this study, antitoxin production against BoNT/A1 using Halla horse bred on Jeju Island was investigated.

BoNTs are protein toxins, which are associated with a high mortality rate, when inhaled or ingested even in small amounts [3], therefore, antitoxin therapy is indispensable for the treatment of botulism as well as appropriate antibiotic therapy. For this reason, various antitoxins against botulinum toxins have been developed persistingly. BabyBIG, is a human-derived antitoxin against serotypes A and $B$, and approved for use in infants and toddlers. However, the efficacy of BabyBIG is merely $1-4 \%$ of BATAB, Sanofi Pasteur's botulinum antitoxin. H-BAT (Emergent Biosolutions Inc.) is a polyclonal hyperimmune product manufactured from BoNT toxoids or toxin-immunized equine, and employed to treat botulism in adults or children. Also, this product contains antitoxins against seven botulinum toxin serotypes (A-G). Hence, H-BAT is currently the only treatment for botulism poisoning, and can be used in adults and pediatric patients [24, 25, 44]. However, the use of H-BAT is mostly restricted within the US, thus, the access to botulinum antitoxins under emergency situations is limited in other countries.

In the present study, we immunized Halla horse with BoNT/A1-HCR to obtain an antitoxin against BoNT/A1 consisting of neutralizing antibodies. The heavy chain domain of BoNTs has been used as a vaccine for botulism, and could induce high levels of neutralizing antibodies to efficiently protect against BoNTs. In addition, it is shown to be a good immunogen for antitoxins in mice and nonhuman primates [45-48]. The previous reports showed that BoNT/A-heavy chain (amino acid 868 through 1296), BoNT/C-heavy chain (425 C-terminal amino acid of the heavy chain), and BoNT/D-heavy chain (413 C-terminal amino acid of the heavy chain) could induce immune responses in horses [48, 49]. In general, inactivated botulinum toxin was used as an antigen for the production of BoNT/A1 antitoxin, such as H-BAT, because the production of toxoid is expensive, and the preparation involves a hazardous detoxification process [45, 46]. BoNT/A toxin is produced by Clostridium botulinum as a form of complex with non-toxic non-hemagglutinin $\mathrm{A}$ (NTNHA), hemagglutinin (HA)-17, HA-33, and HA-70, under regulations with high biosafety levels, and the yield 
of toxin production is relatively poor $(\sim 1 \mathrm{mg} / \mathrm{l})[45,50,51]$. Therefore, current equine polyclonal hyperimmune product includes antibodies against NTNHA and HAs. We used BoNT / A1-HCR (amino acid 876 through 1296) as antigens, instead of BoNT/A toxoid, to avoid the risks in large-scale production of toxin and manufacturing issues according to the biosafety regulations. Furthermore, it was estimated that BoNT/A1-HCR could be good immunogen in Halla horses in previous studies [48, 49].

After the immunization of BoNT/A1-HCR in Halla horse, the highest antibody titer was obtained at week 4 , and subsequently a titer was maintained as around 1,000. In the case of rabbits, the highest antibody titer was accomplished up to 150,000 after five injections of BoNT/ A1-HCR (Fig. 2B). These results are appeared to be due to rabbits producing antibodies with higher titer compared to other animal species $[52,53]$. Moreover, this difference in titer between horse and rabbit might have occurred by the difference in adjuvant, antigen doses, immunization schedule, or species. However, the serum from BoNT/A1HCR-immunized Halla horse had a competent neutralization activity against BoNT/A1 toxins regardless of the relatively low titer compared to that of brown horses. The equine serum from week 24 displayed neutralizing efficacy in vitro, and neutralized 10,000 $\mathrm{LD}_{50}$ of BoNT/A1 in the mouse protection assay corresponding to the standard of international units. It was estimated that $20 \mu \mathrm{l}$ of the equine serum had $>1 \mathrm{IU}$ of neutralizing activity in vivo $(>50 \mathrm{IU} / \mathrm{ml})$.

BoNT/A consists of four subtypes from BoNT/A1 to BoNT/A4, and the amino acid variation between them is about $15 \%$ or less [54]. These variants have been reported to affect binding affinities of the BoNTs to anti-BoNT/A monoclonal antibodies $[55,56]$. In the previous study, a high dose vaccination of BoNT/A HCR protected mice from challenge by heterologous BoNT/A subtype A1-A4 [57]. Therefore, our BoNT/A1-HCR equine serum is expected to contain polyclonal antibodies against BoNT/ A1, and could protect against BoNT/A2-A4. However, the neutralization efficacy may be dependent on the variation in amino acid sequence of BoNT/A subtypes.

To fit the data, we used the heterogeneous ligand model (Fig. 4B). The heterogeneous ligand model is appropriate to match the actual curves because polyclonal antibodies could bind different sites on the same ligand molecule [58]. In this analysis, our purified $\mathrm{F}\left(\mathrm{ab}^{\prime}\right)_{2}$ revealed $3.16 \mathrm{nM}$ of $\mathrm{K}_{\mathrm{D} 1}$ and $4.79 \mathrm{nM} \mathrm{K} \mathrm{K}_{\mathrm{D} 2}$ values. In former studies, monoclonal antibodies against BoNT/A toxin showed $\mathrm{K}_{\mathrm{D}}$ values from $10^{-11}(10 \mathrm{pM})$ to $10^{-8}(10 \mathrm{nM})[56,59]$. The $\mathrm{K}_{\mathrm{D}}$ value of a monoclonal antibody might be higher than that of a polyclonal antibody, because the $K_{D}$ value of a monoclonal antibody was derived from a single epitope, whereas the $K_{\mathrm{D}}$ value of a polyclonal antibody was from the mixture of a number of epitopes [60].

Several reports suggested that the combination of serotype-specific monoclonal antibodies showed strong synergic effects corresponding to $\sim 400$-fold enhancement in their neutralizing activity against BoNTs, and these results suggested that the combination of antibodies can be a considerable strategy for synergic neutralization effect against BoNT/A [61-64]. In our neutralization analysis, due to the absence of the $F_{c}$ region, the Fc-mediated clearance of antibody-toxin complexes from the serum for synergic neutralization effect may not be revealed in our equine $\mathrm{F}\left(\mathrm{ab}^{\prime}\right)_{2}$ antitoxin treatments. However, no differences were observed in the in vivo neutralizing activity at the same concentrations when we compared the neutralizing activity between $\operatorname{IgG}$ and $\mathrm{F}\left(\mathrm{ab}^{\prime}\right)_{2}$ in mice (data not shown). Therefore, the synergic neutralizing effect of our equine $\mathrm{F}\left(\mathrm{ab}^{\prime}\right)_{2}$ antitoxins may exert through the simultaneous binding of interfering polyclonal antibodies to multiple cell binding sites on the BoNT/A1 toxin, and block the entry of BoNT/A toxin into cells $[62,63]$.

The toxicities caused by equine antiserum are mainly due to hypersensitivity reactions (e.g., anaphylaxis, urticarial, serum sickness), so the equine antitoxins have been partially despeciated by enzymatic cleavage of the allogenic Fc region $[20,65,66]$. We also cleaved the Fc regions to minimize the toxicity of our equine antitoxin through the pepsin treatment (Fig. 4). However, the purified $\mathrm{F}\left(\mathrm{ab}^{\prime}\right)_{2}$ contained a small residual of intact IgG that may retain hypersensitivity reactions [67]. Despite the risks of immediate hypersensitivity and sensitization to equine antitoxins, the development of equine antitoxins is important because of the usage of emergent drugs to save the patients exposed to the toxin.

In conclusion, we developed BoNT/A1 equine antitoxin in Halla horse which is well known for its superior immunity and resistance against diverse diseases using BoNT/ A1-HCR as an antigen. Our results demonstrate that BoNT/A1-HCR is useful for producing BoNT/A1 equine antitoxin, and it could produce antitoxin from Korean domestic horses. Finally, our findings provide an effective protocol for producing antitoxin in Halla horses, which may contribute to the establishment of a system for emergency treatment using horse sera to cope with various infectious diseases that may occur in the Republic of Korea. 


\section{Acknowledgments}

This work was supported by the Agency for Defense Development [UC140013ID] of the Republic of Korea.

\section{Conflict of interest}

Jun Young Choi and Young Kee Shin own some stocks in ABION Inc., and Jun Young Choi, Na Young Kim, and Kyungeui Park hold stock options in ABION Inc.

\section{References}

1. Anderson PD. 2012. Bioterrorism: toxins as weapons. J. Pharm. Pract. 25: 121-129.

2. Jernigan JA, Stephens DS, Ashford DA, Omenaca C, Topiel MS, Galbraith M, et al. 2001. Bioterrorism-related inhalational anthrax: the first 10 cases reported in the United States. Emerg. Infect. Dis. 7: 933-944.

3. Shukla HD, Sharma SK. 2005. Clostridium botulinum: a bug with beauty and weapon. Crit. Rev. Microbiol. 31: 11-18.

4. Tucker JB. 1999. Historical trends related to bioterrorism: an empirical analysis. Emerg. Infect. Dis. 5: 498-504.

5. Hedeland M, Moura H, Baverud V, Woolfitt AR, Bondesson U, Barr JR. 2011. Confirmation of botulism in birds and cattle by the mouse bioassay and Endopep-MS. J. Med. Microbiol. 60: 1299-1305.

6. Sonnabend O, Sonnabend W, Heinzle R, Sigrist T, Dirnhofer R, Krech U. 1981. Isolation of Clostridium botulinum type $G$ and identification of type $G$ botulinal toxin in humans: report of five sudden unexpected deaths. J. Infect. Dis. 143: 22-27.

7. Barash JR, Arnon SS. 2014. A novel strain of Clostridium botulinum that produces type $\mathrm{B}$ and type $\mathrm{H}$ botulinum toxins. J. Infect. Dis. 209: 183-191.

8. Huang W, Foster JA, Rogachefsky AS. 2000. Pharmacology of botulinum toxin. J. Am. Acad. Dermatol. 43: 249-259.

9. Baldwin MR, Bradshaw M, Johnson EA, Barbieri JT. 2004. The C-terminus of botulinum neurotoxin type A light chain contributes to solubility, catalysis, and stability. Protein Expr. Purif. 37: 187-195.

10. Rossetto O, Deloye F, Poulain B, Pellizzari R, Schiavo G, Montecucco C. 1995. The metallo-proteinase activity of tetanus and botulism neurotoxins. J. Physiol. Paris 89: 43-50.

11. Park JB, Simpson LL. 2003. Inhalational poisoning by botulinum toxin and inhalation vaccination with its heavychain component. Infect. Immun. 71: 1147-1154.

12. Arnon SS, Damus K, Chin J. 1981. Infant botulism: epidemiology and relation to sudden infant death syndrome. Epidemiol. Rev. 3: 45-66.
13. Dhaked RK, Singh MK, Singh P, Gupta P. 2010. Botulinum toxin: bioweapon \& magic drug. Indian J. Med. Res. 132: 489503.

14. Hauschild AHW. 1993. Epidemiology of human foodborne botulism., pp. 69-104. Clostridium botulinum: Ecology and Control in Foods, Ed. CRC Press,

15. Schiavo G, Benfenati F, Poulain B, Rossetto O, Polverino de Laureto P, DasGupta BR, et al. 1992. Tetanus and botulinum-B neurotoxins block neurotransmitter release by proteolytic cleavage of synaptobrevin. Nature 359: 832-835.

16. Schiavo G, Malizio C, Trimble WS, Polverino de Laureto P, Milan G, Sugiyama H, et al. 1994. Botulinum G neurotoxin cleaves VAMP/synaptobrevin at a single Ala-Ala peptide bond. J. Biol. Chem. 269: 20213-20216.

17. Schiavo G, Shone CC, Rossetto O, Alexander FC, Montecucco C. 1993. Botulinum neurotoxin serotype $\mathrm{F}$ is a zinc endopeptidase specific for VAMP/synaptobrevin. $J$. Biol. Chem. 268: 11516-11519.

18. Blasi J, Chapman ER, Yamasaki S, Binz T, Niemann H, Jahn R. 1993. Botulinum neurotoxin C1 blocks neurotransmitter release by means of cleaving HPC-1/syntaxin. EMBO J. 12: 4821-4828.

19. Schiavo G, Santucci A, Dasgupta BR, Mehta PP, Jontes J, Benfenati $\mathrm{F}$, et al. 1993. Botulinum neurotoxins serotypes A and E cleave SNAP-25 at distinct $\mathrm{COOH}$-terminal peptide bonds. FEBS Lett. 335: 99-103.

20. Arnon SS, Schechter R, Maslanka SE, Jewell NP, Hatheway CL. 2006. Human botulism immune globulin for the treatment of infant botulism. N. Engl. J. Med. 354: 462-471.

21. Hu CC, Yin J, Chau D, Cherwonogrodzky JW, Hu WG. 2014. Active immunity induced by passive IgG postexposure protection against ricin. Toxins (Basel) 6: 380-393.

22. Li D, Mattoo P, Keller JE. 2012. New equine antitoxins to botulinum neurotoxins serotypes A and B. Biologicals 40: 240-246.

23. Long SS. 2007. Infant botulism and treatment with BIG-IV (BabyBIG). Pediatr. Infect. Dis. J. 26: 261-262.

24. Rosow LK, Strober JB. 2015. Infant botulism: review and clinical update. Pediatr. Neurol. 52: 487-492.

25. Diseases ZFDaUSAMRIfI. 2011. Medical Management of Biological Casualties Handbook, pp. 120-121. 7th Ed. United States Department of Defense.

26. Hill SE, Iqbal R, Cadiz CL, Le J. 2013. Foodborne botulism treated with heptavalent botulism antitoxin. Ann. Pharmacother. 47: e12.

27. Hatheway CH, Snyder JD, Seals JE, Edell TA, Lewis GE, Jr. 1984. Antitoxin levels in botulism patients treated with trivalent equine botulism antitoxin to toxin types A, B, and E. J. Infect. Dis. 150: 407-412.

28. Tacket CO, Shandera WX, Mann JM, Hargrett NT, Blake PA. 1984. Equine antitoxin use and other factors that predict outcome in type A foodborne botulism. Am. J. Med. 76: 794798. 
29. Kim NY, Chang DS, Kim Y, Kim CH, Hur GH, Yang JM, et al. 2015. Enhanced immune response to DNA vaccine encoding Bacillus anthracis PA-D4 protects mice against anthrax spore challenge. PLoS One 10: e0139671.

30. Seo JH, Park KD, Lee HK, Kong HS. 2016. Genetic diversity of Halla horses using microsatellite markers. J. Anim. Sci. Technol. 58: 40.

31. GJ C. 2006. Genetic relationship among the Korean native and alien horses estimated by microsatellite polymorphism. Asian-Australas. J. Anim. Sci. 19: 784-788.

32. Choi JY, Shin S, Kim NY, Son WS, Kang TJ, Song DH, et al. 2017. A novel staphylococcal enterotoxin B subunit vaccine candidate elicits protective immune response in a mouse model. Toxicon 131: 68-77.

33. Pellett S. 2013. Progress in cell based assays for botulinum neurotoxin detection. Curr. Top. Microbiol. Immunol. 364: 257285.

34. Ruthel G, Burnett JC, Nuss JE, Wanner LM, Tressler LE, Torres-Melendez E, et al. 2011. Post-intoxication inhibition of botulinum neurotoxin serotype A within neurons by small-molecule, non-peptidic inhibitors. Toxins (Basel) 3: 207217.

35. Bowmer EJ. 1963. Preparation and assay of the international standards for clostridium botulinum types a, B, C, D and E antitoxins. Bull. World Health Organ. 29: 701-709.

36. Yu CH, Song DH, Choi JY, Joe HE, Jeong WH, Hur GH, et al. 2018. A mutated recombinant subunit vaccine protects mice and guinea pigs against botulinum type A intoxication. Hum. Vaccin. Immunother. 14: 329-336.

37. Jones RG, Corbel MJ, Sesardic D. 2006. A review of WHO International Standards for botulinum antitoxins. Biologicals 34: 223-226.

38. Asokan M, Rudicell RS, Louder M, McKee K, O'Dell S, Stewart-Jones G, et al. 2015. Bispecific antibodies targeting different epitopes on the HIV-1 envelope exhibit broad and potent neutralization. J. Virol. 89: 12501-12512.

39. Figuera-Losada M, LoGrasso PV. 2012. Enzyme kinetics and interaction studies for human JNK1beta1 and substrates activating transcription factor 2 (ATF2) and c-Jun Nterminal kinase (c-Jun). J. Biol. Chem. 287: 13291-13302.

40. Wang C, Zeng X, Zhou Z, Zhao J, Pei G. 2016. beta-arrestin1 contributes to brown fat function and directly interacts with PPARalpha and PPARgamma. Sci. Rep. 6: 26999.

41. Larreche S, Mion G, Mayet A, Verret C, Puidupin M, Benois $A$, et al. 2011. Antivenin remains effective against African Viperidae bites despite a delayed treatment. Am. J. Emerg. Med. 29: 155-161.

42. Seong WK JK, Shin KS, Kim HH, Park KS, Oh HB. 1999. Immunological characterization of the venoms from Korean snakes of the genus Agkistrodon for therapeutic antivenin production. Korean J. Vet. Public Health. 23: 21-31.

43. Control CfD. 2004. Epidemiology and Prevention of VaccinePreventable Diseases, pp. 65-73. 8th Ed.
44. Kodihalli S, Emanuel A, Takla T, Hua Y, Hobbs C, LeClaire R, et al. 2017. Therapeutic efficacy of equine botulism antitoxin in Rhesus macaques. PLoS One 12: e0186892.

45. Byrne MP, Smith LA. 2000. Development of vaccines for prevention of botulism. Biochimie 82: 955-966.

46. Middlebrook JL. 2005. Production of vaccines against leading biowarfare toxins can utilize DNA scientific technology. Adv. Drug. Deliv. Rev. 57: 1415-1423.

47. Smith LA, Rusnak JM. 2007. Botulinum neurotoxin vaccines: past, present, and future. Crit. Rev. Immunol. 27: 303-318.

48. Stahl C, Unger L, Mazuet C, Popoff M, Straub R, Frey J. 2009. Immune response of horses to vaccination with the recombinant $\mathrm{Hc}$ domain of botulinum neurotoxin types $\mathrm{C}$ and D. Vaccine 27: 5661-5666.

49. Yu YZ, Zhang SM, Wang WB, Du Y, Zhu HQ, Wang RL, et al. 2010. Development and preclinical evaluation of a new $\mathrm{F}\left(\mathrm{ab}^{\prime}\right)(2)$ antitoxin against botulinum neurotoxin serotype A. Biochimie 92: 1315-1320.

50. Cheng LW, Onisko B, Johnson EA, Reader JR, Griffey SM, Larson AE, et al. 2008. Effects of purification on the bioavailability of botulinum neurotoxin type A. Toxicology 249: 123-129.

51. Duff JT, Wright GG, Klerer J, Moore DE, Bibler RH. 1957. Studies on immunity to toxins of Clostridium botulinum. I. A simplified procedure for isolation of type A toxin. J. Bacteriol. 73: 42-47.

52. Gaur PK, El-Nakib O, Chu FS. 1980. Comparison of antibody production against aflatoxin B1 in goats and rabbits. Appl. Environ. Microbiol. 40: 678-680.

53. HF S. 1994. CHAPTER 20 - Polyclonal Antibody Production, pp. 435-448. The Biology of the Laboratory Rabbit, 2nd Ed. Academic Press,

54. Hill KK, Smith TJ, Helma CH, Ticknor LO, Foley BT, Svensson RT, et al. 2007. Genetic diversity among Botulinum Neurotoxin-producing clostridial strains. J. Bacteriol. 189: 818-832.

55. Kalb SR, Lou J, Garcia-Rodriguez C, Geren IN, Smith TJ, Moura $\mathrm{H}$, et al. 2009. Extraction and inhibition of enzymatic activity of botulinum neurotoxins/A1, / $\mathrm{A} 2$, and / $\mathrm{A} 3$ by a panel of monoclonal anti-BoNT/A antibodies. PLoS One 4: e5355.

56. Smith TJ, Lou J, Geren IN, Forsyth CM, Tsai R, Laporte SL, et al. 2005. Sequence variation within botulinum neurotoxin serotypes impacts antibody binding and neutralization. Infect. Immun. 73: 5450-5457.

57. Henkel JS, Tepp WH, Przedpelski A, Fritz RB, Johnson EA, Barbieri JT. 2011. Subunit vaccine efficacy against Botulinum neurotoxin subtypes. Vaccine 29: 7688-7695.

58. Henseleit A, Pohl C, Kaltenbach HM, Hettwer K, Simon K, Uhlig S, et al. 2015. Kinetic analyses of data from a human serum albumin assay using the liSPR system. Biosensors (Basel) 5: 27-36. 
59. Nowakowski A, Wang C, Powers DB, Amersdorfer P, Smith TJ, Montgomery VA, et al. 2002. Potent neutralization of botulinum neurotoxin by recombinant oligoclonal antibody. Proc. Natl. Acad. Sci. USA 99: 11346-11350.

60. Sikarwar B, Sharma PK, Srivastava A, Agarwal GS, Boopathi M, Singh B, et al. 2014. Surface plasmon resonance characterization of monoclonal and polyclonal antibodies of malaria for biosensor applications. Biosens. Bioelectron. 60: 201-209.

61. Chen C, Wang S, Wang H, Mao X, Zhang T, Ji G, et al. 2012. Potent neutralization of botulinum neurotoxin/B by synergistic action of antibodies recognizing protein and ganglioside receptor binding domain. PLoS One 7: e43845.

62. Diamant E, Lachmi BE, Keren A, Barnea A, Marcus H, Cohen S, et al. 2014. Evaluating the synergistic neutralizing effect of anti-botulinum oligoclonal antibody preparations. PLoS One 9: e87089.
63. Diamant E, Torgeman A, Ozeri E, Zichel R. 2015 Monoclonal antibody combinations that present synergistic neutralizing activity: a platform for next-generation antitoxin drugs. Toxins (Basel) 7: 1854-1881.

64. Ngundi MM, Meade BD, Little SF, Quinn CP, Corbett CR, Brady RA, et al. 2012. Analysis of defined combinations of monoclonal antibodies in anthrax toxin neutralization assays and their synergistic action. Clin. Vaccine Immunol. 19: 731-739.

65. Black RE, Gunn RA. 1980. Hypersensitivity reactions associated with botulinal antitoxin. Am. J. Med. 69: 567-570.

66. Greenfield RA, Bronze MS. 2003. Prevention and treatment of bacterial diseases caused by bacterial bioterrorism threat agents. Drug. Discov. Today 8: 881-888.

67. Arnon SS, Schechter R, Inglesby TV, Henderson DA, Bartlett JG, Ascher MS, et al. 2001. Botulinum toxin as a biological weapon: medical and public health management. JAMA 285: 1059-1070. 